\title{
Pet exposure and risk of atopic dermatitis at the pediatric age: A meta-analysis of birth cohort studies
}

\author{
Claudio Pelucchi, ScD, ${ }^{a}$ Carlotta Galeone, PhD, ${ }^{a, b}$ Jean-François Bach, MD, DSc, ${ }^{c, d}$ Carlo La Vecchia, MD, ${ }^{a, b}$ and \\ Liliane Chatenoud, ScD ${ }^{\mathbf{a}}$ Milan, Italy, and Paris, France
}

Background: Findings on pet exposure and the risk of atopic dermatitis (AD) in children are inconsistent.

Objective: With the aim to summarize the results of exposure to different pets on AD, we undertook a meta-analysis of epidemiologic studies on this issue.

Methods: In August 2012, we conducted a systematic literature search in Medline and Embase. We included analytic studies considering exposure to dogs, cats, other pets, or pets overall during pregnancy, infancy, and/or childhood, with AD assessment performed during infancy or childhood. We calculated summary relative risks and $95 \%$ CIs using both fixed- and random-effects models. We computed summary estimates across selected subgroups.

Results: Twenty-six publications from 21 birth cohort studies were used in the meta-analyses. The pooled relative risks of AD for exposure versus no exposure were 0.72 (95\% CI, 0.61-0.85; $I^{2}=46 \%$; results based on 15 studies) for exposure to dogs, 0.94 (95\% CI, 0.76-1.16; $I^{2}=54 \%$; results based on 13 studies) for exposure to cats, and $0.75\left(95 \% \mathrm{CI}, 0.67-0.85 ; I^{2}=54 \%\right.$; results based on 11 studies) for exposure to pets overall. No

heterogeneity emerged across the subgroups examined, except for geographic area.

Conclusion: This meta-analysis reported a favorable effect of exposure to dogs and pets on the risk of $\mathrm{AD}$ in infants or children, whereas no association emerged with exposure to cats. (J Allergy Clin Immunol 2013;132:616-22.)

Key words: Atopic dermatitis, child, epidemiology, hygiene hypothesis, pets

The hygiene hypothesis has been proposed as a possible explanation for the apparent increasing prevalence of allergic diseases, including atopic dermatitis (AD), registered during the last decades in several high-income countries. ${ }^{1}$ This hypothesis assumes that a reduced exposure to infectious agents in early life can affect the development of the immune system, leading to increased susceptibility to allergic and autoimmune disorders. $^{1,2}$

\footnotetext{
$\overline{\text { From }}{ }^{\mathrm{a}}$ IRCCS - Istituto di Ricerche Farmacologiche Mario Negri, Milan; ${ }^{\mathrm{b}}$ the Department of Clinical Sciences and Community Health, University of Milan; ${ }^{\mathrm{c}}$ Université Paris Descartes, INSERM, Paris; and ${ }^{\mathrm{d}}$ INSERM, Unité 1013, Paris.

Supported by the European Research Council, grant agreement no. 250290.

Disclosure of potential conflict of interest: The authors have been supported by one or more grants from the European Research Council.

Received for publication February 26, 2013; revised March 28, 2013; accepted for publication April 9, 2013.

Available online May 24, 2013.

Corresponding author: Claudio Pelucchi, ScD, IRCCS - Istituto di Ricerche Farmacologiche "Mario Negri," Via Giuseppe La Masa 19, 20156 Milan, Italy. E-mail: claudio. pelucchi@marionegri.it.

0091-6749/\$36.00

(C) 2013 American Academy of Allergy, Asthma \& Immunology

http://dx.doi.org/10.1016/j.jaci.2013.04.009
}

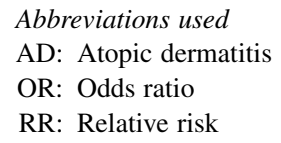

Along these lines, regular contact with animals and thus increased exposure to microbial products, including endotoxins, in pregnancy or during early life (ie, before the inception of asthma and allergies) has been linked to reduced atopic sensitization $^{3}$ and then to various allergic diseases. ${ }^{4-11}$ In particular, a decreased risk of asthma and hay fever, but not $\mathrm{AD}$, emerged in children of farmers, ${ }^{9}$ pointing toward a favorable role of exposure to livestock and related bacterial components. ${ }^{12}$ In a large birth cohort study from Germany, the development of asthma was not related to cat and mite allergen exposure in the first years of life or to cat ownership, although sensitization to mite and cat allergens was associated with indoor exposure. ${ }^{13}$ Another study conducted in a rural setting considered the role of pets. ${ }^{10}$ This found an inverse relation between dog exposure at interview and diagnoses of asthma and hay fever, although the associations were somewhat attenuated after allowing for livestock exposure. On the other hand, only an intensive exposure to cats, but not to pets in general, was found to prevent asthma in a population of schoolchildren not living on a farm. ${ }^{11}$

Earlier reviews and meta-analyses tried to summarize the role of exposure to pets on asthma and rhinitis. A meta-analysis reported that exposure to dogs, but not cats, increased the risk of asthma, whereas exposure to any furry pet decreased the risk of rhinitis by approximately $20 \% .{ }^{14}$ However, this meta-analysis included prevalence studies and was criticized on this and other bases. ${ }^{15}$ A subsequent systematic review indicated that most birth cohort studies report no effect of early-life pet exposure on the development of asthma and that conflicting findings emerged across different study designs and methods of assessment of pet exposure. ${ }^{15,16}$ Similarly, no effect on asthma or allergic rhinitis in children aged 6 to 10 years was found in a recent pooled analysis of birth cohort studies. ${ }^{17}$

Various, mainly narrative reviews have also been conducted on $\mathrm{AD}$, which is often the first clinical step in the atopic pathway, reporting a possible inverse relation with early pet exposure. ${ }^{18,19}$ Several birth cohort studies have recently provided new results on the relation between exposure to pets, mainly dogs or cats, and the risk of AD in children. ${ }^{5,7,20-25}$ Thus there is the need to quantify the role of exposure to different pets on the cause of AD by using a meta-analytic approach and to examine the association in selected subgroups to address potential methodological shortcomings or underlying factors, if any were present, explaining the relation. In particular, likely confounding roles of family history of allergic diseases through an effect of pet avoidance, as well as of social class and maternal smoking habits, have been reported. ${ }^{26,27}$ 
With the aim to summarize the information on the relation between exposure to various pets and $\mathrm{AD}$ in infants and children and to address the role of several covariates, we conducted a formal systematic review and a meta-analysis of epidemiologic studies on the issue.

\section{METHODS}

This systematic review was conducted according to the Meta-analysis of Observational Studies in Epidemiology (MOOSE) guidelines for reporting meta-analysis of observational studies. ${ }^{28}$ We registered this review in the International Prospective Register of Systematic Reviews (PROSPERO, registration no. CRD42012002908), describing in advance the aims and methods of our investigation. ${ }^{29}$

In August 2012 we performed a systematic literature search of the Medline and Embase databases for cohort and case-control studies reporting data on exposure to pets and AD in infants and children. The following search string, restricted to the English language, was used in PubMed: "(case-control OR cohort OR prospective OR retrospective) AND (eczema OR dermatitis) AND (pregnancy OR pregnant OR child OR children OR infant OR adolescent) AND (animals OR pets OR dogs OR cats).” A similar combination was adopted for the Embase search.

Two review team members (C.P. and C.G.) retrieved and independently assessed the potentially relevant articles and checked the reference lists of all articles of interest to obtain other pertinent publications. Abstracts and unpublished studies were not included. No studies were excluded a priori for weakness of design or data quality, and we did not assign quality scores to the studies. Each publication identified was included in the analysis if the following criteria were met: (1) cohort or case-control studies considering exposure to dogs, cats, other pets, or pets overall (ie, pet keeping or regular contacts with pets) during pregnancy, infancy, and/or childhood; (2) AD assessment performed during infancy or childhood (ie, $\leq 12$ years of age); and (3) reported estimates of odds ratios (ORs) and corresponding 95\% CIs or information sufficient to calculate them for occurrence of $\mathrm{AD}$. We excluded studies that were (1) cross-sectional; (2) focused on measures of pet exposure other than pet keeping (eg, sensitization to dogs or cats and pet allergens/endotoxins measured in the mattress, at home, or at school); (3) studies reporting outcomes in adolescents or adults; and (4) studies focused on the prognosis of AD.

We collected data on the number of subjects with and without the disease in the exposed (ie, to dogs, cats, other pets, or pets overall) and nonexposed groups; risk estimates (crude and/or adjusted ORs, hazard ratios, or rate ratios, hereafter collectively defined as relative risks [RRs]) and the corresponding 95\% CIs at any available age end point. Furthermore, we abstracted information on potential sources of heterogeneity or bias across studies, including details on the population enrolled (ie, children with a family history of atopic diseases or unselected children), geographic area, period or periods of pet exposure, outcome assessors, covariate or covariates adjusted for in the statistical models, and subgroup analyses. Discrepancies between review team members were discussed and resolved.

We pooled the RR estimates of each study according to exposure to different pets. For those studies providing only frequency (or percentage) distributions, we calculated unadjusted ORs and their 95\% CIs from the outcome distribution of exposed and nonexposed children, as reported in the publications. When multiple estimates from the same study (from $\geq 1$ publications) were available, we included in the main meta-analysis the one study that fulfilled the following ordered criteria: (1) outcome assessment occurring at an earlier age $\mathrm{e}^{4,5,22,30,31} ;$ (2) outcome assessment over a time period, rather than at a given end point (eg, $\mathrm{AD}$ up to age 1 year was preferred to $\mathrm{AD}$ at age 1 year $)^{4}$; (3) pet exposure occurring at an earlier age ${ }^{32,33}$; (4) risk estimate adjusted for the largest number of the terms family history of allergic diseases, parental education/income, parental smoking ${ }^{34,35}$; and (5) exposure to any pet rather than to "dog or cat" only. ${ }^{36}$

We calculated summary RR estimates of AD by using both fixed-effects models with the inverse variance method (ie, computing an average effect by weighting the $\log$ OR of each study according to the inverse of the sampling variance) and random-effects models, which consider both within- and between-study variations by using the DerSimonian and Laird method. ${ }^{37-39}$ We presented RRs from random-effects models that assume that the exposure effects observed in the studies are a random sample from a distribution of exposure effects, thus yielding a more global and conservative estimate. ${ }^{39}$ Furthermore, random-effects models have the advantage of increasing the accuracy of the exposure estimates because the information from the study error stratum is used in addition to that from the residual stratum. Heterogeneity between estimates was assessed by using the $\chi^{2}$ test and defined as a $P$ value of less than .10 , and inconsistency was measured by using the $I^{2}$ statistic. ${ }^{40} \mathrm{We}$ also computed summary estimates in several subgroups, including geographic area, family history of allergic disease, age and period of outcome assessment, period of exposure, and adjustment for family history of allergic disease, parental education/income, or parental smoking. In stratified analyses we presented RRs from random-effects models because the number of studies and hence the power of the heterogeneity test was low. We used meta-regression to test heterogeneity between subgroups for study-level, 2-strata covariates or a heterogeneity test otherwise. ${ }^{41}$ The presence of publication bias was assessed by examining the funnel plot and applying the tests proposed by Begg and Mazumdar ${ }^{42}$ and Egger et al. ${ }^{43}$ All the statistical analyses were performed with STATA software (version 11; StataCorp, College Station, Tex).

\section{RESULTS}

Fig 1 shows the selection process of publications in a flowchart. Overall, 307 publications were identified in PubMed and 93 in Embase. By examining the title and abstract, approximately three fourths of the articles were excluded as irrelevant (eg, studies of food allergies, atopic or dermatologic diseases other than $\mathrm{AD}$, sensitization to several allergens, dust mite exposures, and treatment/prognosis and review articles). Furthermore, 20 of the retained publications were present in both databases, leaving 94 unique publications for full-text examination. The review of the reference lists of these publications led to the identification of 7 additional reports, for a total of 101 articles. After in-depth consideration, 72 publications were excluded (mostly because they lacked data for pets or analyzed outcomes other than $\mathrm{AD}$, were cross-sectional studies, or lacked data from original studies). Thus there were 29 publications that reported original data on pet exposure and the risk of $\mathrm{AD}$ from cohort studies. These were the basis for our meta-analysis. Three of 29 publications ${ }^{44-46}$ reported duplicate data with other articles and thus were not used in the overall meta-analysis or in subgroup investigations. These publications were thus not presented in this review.

Table E1 in this article's Online Repository at www.jacionline. org summarizes the main characteristics of the 26 selected publications reporting data on exposure to pets and risk of $\mathrm{AD}^{4-7,20-25,30-36,47-55} \mathrm{~A}$ few articles were multiple publications from the same studies, and therefore data were available from a total of 21 investigations. All of them were birth cohort studies conducted since $1989^{36}$ in various areas of Europe (14 studies, 6 of which were from Scandinavian countries alone), the United States (3 studies), Oceania (3 studies), and Japan (1 study). With reference to pet exposures considered in these 21 studies, 15 reported data for exposure to dogs, 13 to cats, and 11 to pets (we included in the latter category also those studies reporting data for exposure to "dog or cat" only because those were by far the most common domestic animals kept in the populations examined). Results for exposure to other domestic animals were scanty, and thus the subsequent quantitative meta-analyses were restricted to dogs, cats, and pets overall.

Fig 2 reports the results from each study, as well as overall results, by using a random-effects model for the relation between 


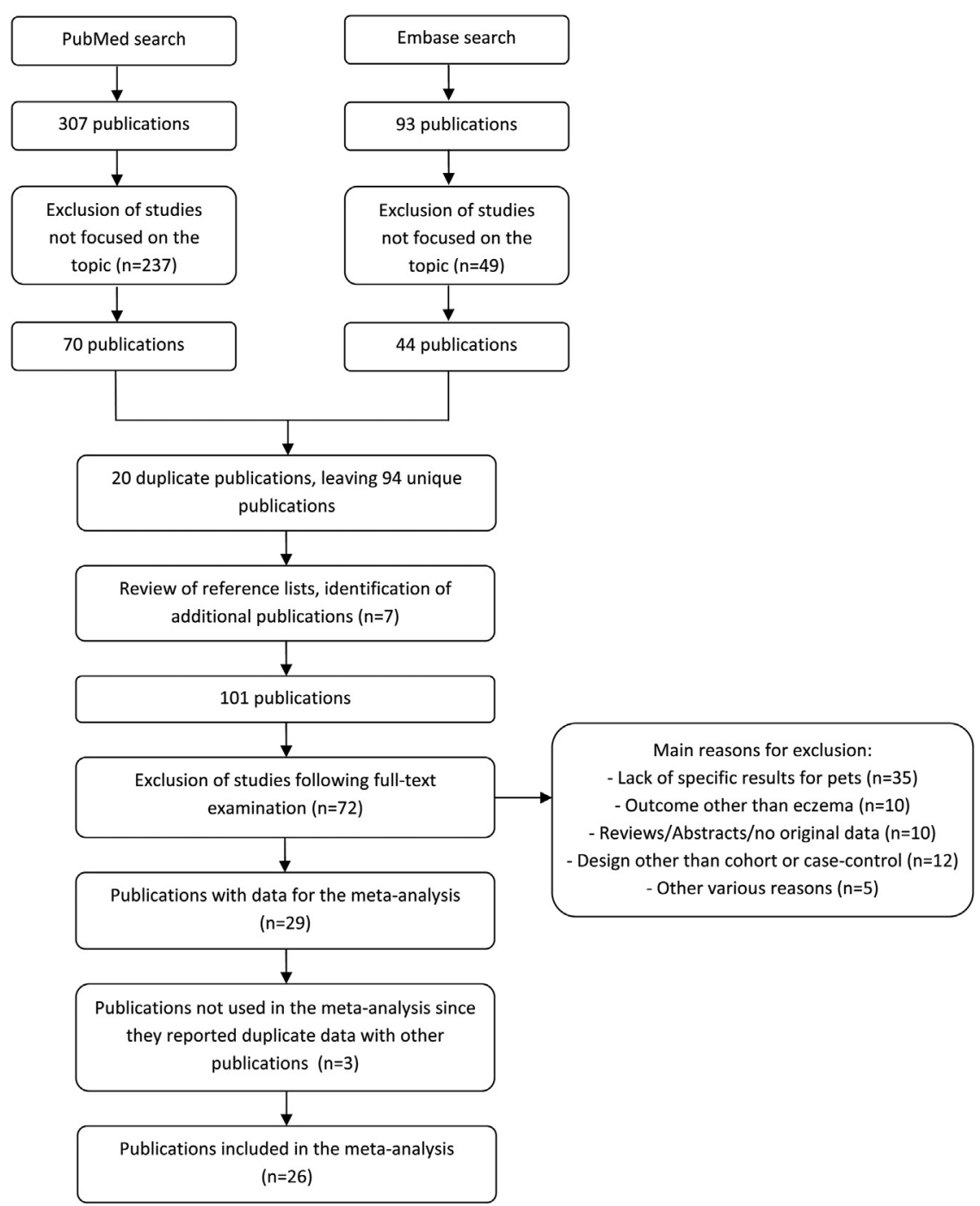

FIG 1. Flowchart for search and selection of publications for the meta-analysis.

exposure to dogs (Fig 2,A), cats (Fig 2,B), and pets overall (Fig 2, $C$ ) and the risk of AD in infants or children. Twelve of $15 \mathrm{RRs}$ for dog exposure were below unity. The pooled RR of AD for exposure versus no exposure to dogs was 0.72 (95\% CI, 0.61-0.85), with moderate inconsistency observed between studies $\left(I^{2}=\right.$ $46 \%$ ). When we used a fixed-effects model, the pooled RR was not materially affected (RR, 0.73; 95\% CI, 0.65-0.82). With reference to cat exposure, 6 of 13 RRs of AD were below unity. When we pooled the estimates, the RR for exposure versus no exposure to cats was 0.94 (95\% CI, 0.76-1.16). Moderate inconsistency emerged between studies $\left(I^{2}=54 \%\right)$. By using a fixed-effects model, the pooled RR was unchanged, and the CI was narrower (RR, 0.94; 95\% CI, 0.82-1.08). Six of 7 studies of any pet exposure (vs no pet exposure) and 3 of 4 studies of dog or cat exposure (vs no dog or cat exposure) found RRs of AD of below unity. The corresponding pooled RRs were $0.78(95 \%$ CI, $\left.0.72-0.85 ; I^{2}=22 \%\right)$ and $0.66\left(95 \% \mathrm{CI}, 0.40-1.06 ; I^{2}=\right.$ $78 \%)$, with no significant heterogeneity between subgroups $(P=.66)$. Pooling all 11 estimates for pet exposure, the overall RR of AD was 0.75 (95\% CI, 0.67-0.85). For the latter analysis, moderate inconsistency between studies was found $\left(I^{2}=54 \%\right)$.
When we performed the analysis of all 11 studies using a fixedeffects model, the pooled RR was 0.80 (95\% CI, 0.75-0.84).

Table I reports the pooled RRs of AD for exposure to dogs, cats, and pets among several subgroups. No major differences emerged across the subgroups examined. Even if the withingroup heterogeneity was moderate or high for several strata (ie, for dog exposure, the $I^{2}$ value was $>60 \%$ in $\geq 1$ subgroup for $8 / 10$ strata considered), point estimates remained consistent between strata. In particular, significant heterogeneity was found only between subgroups of geographic areas for the relation between dog exposure $(P=.005)$ and pet exposure $(P=.02)$ and $\mathrm{AD}$ and subgroups of age at outcome assessment for the relation between pet exposure and $\operatorname{AD}(P=.04)$, although for the latter, no trend in risk was observed. Furthermore, a borderline significant heterogeneity emerged across different study designs in the analysis of $\operatorname{dog}$ exposure $(P=$ .051 ) and AD. Inconsistency within subgroups was high (ie, approximately $70 \%$ ) between studies not adjusted for major potential covariates and absent between adjusted studies when we considered the relation between dog exposure and AD. The opposite finding (ie, no inconsistency between 
A

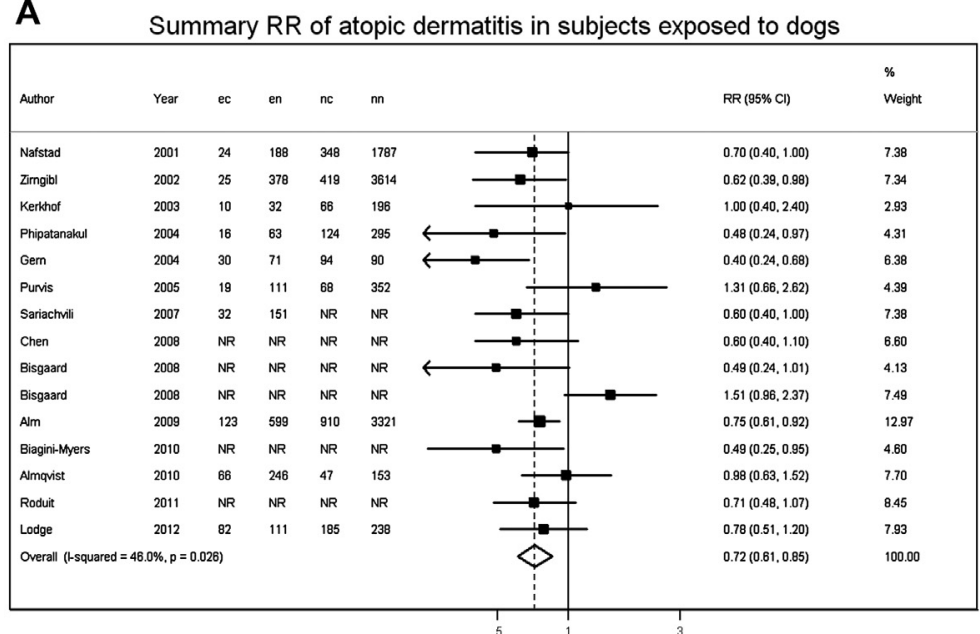

B

Summary RR of atopic dermatitis in subjects exposed to cats

\begin{tabular}{|c|c|c|c|c|c|c|c|}
\hline Author & Year & $\theta c$ & en & ne & $\mathrm{nn}$ & $\operatorname{RR}(95 \% \mathrm{CI})$ & $\begin{array}{l}\% \\
\text { Weight }\end{array}$ \\
\hline Natstad & 2001 & 15 & 154 & 357 & 1821 & $0.50(0.30,0.90)$ & 7.42 \\
\hline Zimgibl & 2002 & 31 & 342 & 413 & 3650 & $0.78(0.52,1.18)$ & 9.49 \\
\hline Kerkhof & 2003 & 21 & 77 & 55 & 151 & $0.60(0.30,1.10)$ & 6.21 \\
\hline Gem & 2004 & 38 & 46 & 86 & 115 & $1.10(0.66 .1 .84)$ & 7.92 \\
\hline Phipatanakul & 2004 & 30 & 74 & 110 & 284 & $1.05(0.65 .1 .69)$ & 8.43 \\
\hline Punis & 2005 & 36 & 201 & 51 & 262 & $0.81(0.44 .1 .49)$ & 6.66 \\
\hline Dunlop & 2006 & 40 & 177 & 167 & 942 & $2.10(1.20,3.60)$ & 7.42 \\
\hline Sariecthili & 2007 & 47 & 162 & NR & NR & $1.00(0.60 .1 .50)$ & 8.73 \\
\hline Bisgaerd & 2009 & NR & NR & NR & NR & $1.28(0.74 .2 .22)$ & 7.42 \\
\hline Almavist & 2010 & 16 & 65 & 97 & 334 & $1.02(0.55 .1 .89)$ & 6.58 \\
\hline Biagini-Myers & 2010 & NR & NR & NR & NR & $0.58(0.26 .1 .26)$ & 4.88 \\
\hline Roduit & 2011 & NR & NR & NR & NR & $0.68(0.46,1.00)$ & 9.84 \\
\hline Lodge & 2012 & 82 & 92 & 185 & 257 & $1.48(0.95,2.29)$ & 9.01 \\
\hline \multicolumn{6}{|c|}{ Overall (1-squared $=54.3 \%, p=0.010$ ) } & $0.94(0.76,1.16)$ & 100.00 \\
\hline
\end{tabular}

C

Summary RR of atopic dermatitis in subjects exposed to pets

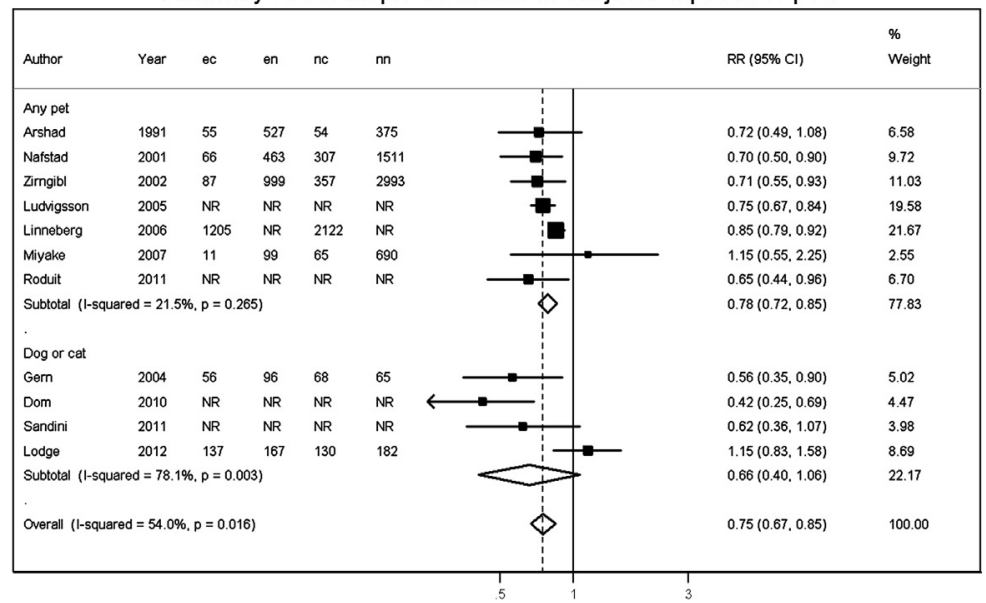

FIG 2. Summary RRs of $A D$ in subjects exposed to dogs (A), cats (B), and pets overall (C). In Fig 2, A, 2 studies from Bisgaard et $\mathrm{al}^{30}$ are reported. Both results are extracted from Bisgaard et al, which are from the COPSAC and MAAS birth cohorts, respectively. The reference category was as follows: no exposure to dogs in Fig 2, $A$; no exposure to cats in Fig 2, B; and no exposure to pets (or to dog or cat) in Fig 2, C.

unadjusted studies and moderate-to-high inconsistency between adjusted studies) emerged for the relations between cat and pet exposure and $\mathrm{AD}$.
Fig E1 in this article's Online Repository at www.jacionline. org shows the funnel plots of studies on exposure to dogs (Fig E1, A), cats (Fig E1, B), and pets overall (Fig E1, C) and 
TABLE I. Summary RRs of AD in relation to exposure to dogs, cats, and pets, according to selected subgroups

\begin{tabular}{|c|c|c|c|c|c|c|c|c|c|}
\hline \multirow[b]{2}{*}{ Subgroup } & \multicolumn{3}{|c|}{ Dogs* } & \multicolumn{3}{|c|}{ Cats } & \multicolumn{3}{|c|}{ Pets $\dagger$} \\
\hline & $\begin{array}{l}\text { No. of } \\
\text { studies }\end{array}$ & RR (95\% Cl) & $r^{2}$ & $\begin{array}{l}\text { No. of } \\
\text { studies }\end{array}$ & RR $(95 \%$ Cl) & $r^{2}$ & $\begin{array}{l}\text { No. of } \\
\text { studies }\end{array}$ & RR $(95 \% \mathrm{Cl})$ & $r$ \\
\hline Europe & 9 & $0.74(0.61-0.90)$ & $40 \%$ & 7 & $0.88(0.63-1.23)$ & $69 \%$ & 8 & $0.73(0.66-0.82)$ & $48 \%$ \\
\hline United States & 3 & $0.44(0.31-0.63)$ & $0 \%$ & 3 & $0.97(0.70-1.34)$ & $0 \%$ & 1 & $0.56(0.35-0.90)$ & - \\
\hline Asia/Oceania & 3 & $0.93(0.70-1.23)$ & $0 \%$ & 3 & $1.13(0.79-1.63)$ & $25 \%$ & 2 & $1.15(0.86-1.54)$ & $0 \%$ \\
\hline \multicolumn{10}{|l|}{ Age at outcome assessment (y) } \\
\hline$>3$ & 7 & $0.84(0.63-1.11)$ & $53 \%$ & 4 & $1.05(0.79-1.40)$ & $0 \%$ & 4 & $0.75(0.53-1.07)$ & $60 \%$ \\
\hline \multicolumn{10}{|l|}{ Period of outcome assessment } \\
\hline At an end point (eg, $\mathrm{AD}$ at age $1 \mathrm{y})$ & 5 & $0.68(0.42-1.10)$ & $73 \%$ & 5 & $0.89(0.60-1.30)$ & $51 \%$ & 3 & $0.70(0.38-1.27)$ & $84 \%$ \\
\hline Up to an end point (eg, AD by age 1 y) & 10 & $0.69(0.56-0.84)$ & $52 \%$ & 9 & $0.95(0.74-1.20)$ & $57 \%$ & 9 & $0.73(0.63-0.82)$ & $51 \%$ \\
\hline \multicolumn{10}{|l|}{ Period of exposure } \\
\hline In pregnancy & 1 & $0.71(0.48-1.07)$ & - & 1 & $0.68(0.46-1.00)$ & - & 2 & $0.80(0.47-1.37)$ & $48 \%$ \\
\hline No & 7 & $0.76(0.53-1.09)$ & $71 \%$ & 6 & $0.93(0.73-1.18)$ & $5 \%$ & 3 & $0.64(0.49-0.84)$ & $0 \%$ \\
\hline Yes & 8 & $0.69(0.59-0.82)$ & $0 \%$ & 7 & $0.97(0.69-1.36)$ & $71 \%$ & 7 & $0.80(0.72-0.90)$ & $50 \%$ \\
\hline \multicolumn{10}{|l|}{ Adjusted for education/income } \\
\hline No & 8 & $0.77(0.58-1.02)$ & $67 \%$ & 7 & $0.90(0.74-1.10)$ & $0 \%$ & 4 & $0.64(0.52-0.80)$ & $0 \%$ \\
\hline Yes & 7 & $0.66(0.54-0.80)$ & $0 \%$ & 6 & $0.96(0.64-1.44)$ & $75 \%$ & 6 & $0.81(0.72-0.91)$ & $53 \%$ \\
\hline \multicolumn{10}{|l|}{$\begin{array}{l}\text { Adjusted for parental smoking/exposure } \\
\text { to ETS }\end{array}$} \\
\hline ( & 8 & $0.69(0.50-0.95)$ & $69 \%$ & 5 & $1.00(0.78-1.28)$ & $0 \%$ & 4 & $0.69(0.54-0.88)$ & $0 \%$ \\
\hline Yes & 7 & $0.73(0.62-0.88)$ & $0 \%$ & 8 & $0.92(0.67-1.26)$ & $69 \%$ & 6 & $0.79(0.71-0.89)$ & $55 \%$ \\
\hline \multicolumn{10}{|l|}{ Family history of allergic diseases } \\
\hline No & 1 & $0.80(0.50-1.40)$ & - & 1 & $0.60(0.30-1.20)$ & - & 2 & $0.79(0.70-0.90)$ & $0 \%$ \\
\hline Yes & 9 & $0.66(0.51-0.85)$ & $40 \%$ & 8 & $0.95(0.72-1.27)$ & $45 \%$ & 5 & $0.74(0.57-0.96)$ & $59 \%$ \\
\hline \multicolumn{10}{|l|}{ Study design } \\
\hline Self-reported by parents & 5 & $0.74(0.53-1.04)$ & $72 \%$ & 3 & $0.80(0.52-1.23)$ & $53 \%$ & 3 & $0.67(0.52-0.85)$ & $59 \%$ \\
\hline Others/mixed types & 3 & $0.59(0.33-1.07)$ & $73 \%$ & 4 & $1.13(0.70-1.84)$ & $61 \%$ & 1 & $0.56(0.35-0.90)$ & - \\
\hline Overall & 15 & $0.72(0.61-0.85)$ & $46 \%$ & 13 & $0.94(0.76-1.16)$ & $54 \%$ & 11 & $0.75(0.67-0.85)$ & $54 \%$ \\
\hline
\end{tabular}

All ORs were calculated by using random-effects models. The sum of studies in subgroups might be higher or lower than the total number of studies because some studies, in turn, provided results for more than 1 subgroup or did not report selected information.

ETS, Environmental tobacco smoke.

$* P$ value for heterogeneity between subgroups of geographic area was .005 .

$\dagger P$ values for heterogeneity between subgroups were .02 for geographic area and 0.04 for age at outcome assessment.

the risk of AD. No evidence of publication bias emerged either by looking at the plots or from Egger and Begg tests for dogs $(P=.62$ and .15 , respectively) and cats $(P=.79$ and .81 , respectively). The funnel plot for pets was moderately asymmetric, but the Egger $(P=.18)$ and Begg $(P=.53)$ tests did not support significant small-study effects.

\section{DISCUSSION}

This meta-analysis of birth cohort studies reported an approximately $25 \%$ decreased risk of $\mathrm{AD}$ for children who experienced exposure to dogs and pets overall, whereas no association emerged with cat exposure. Moderate heterogeneity between studies was reported, and thus results should be considered with caution because global estimates could be influenced by confounding factors not considered in the analyses. There was no evidence of publication bias, notwithstanding the fact that all the identified studies were conducted after the formulation of the hygiene hypothesis in $1989 .^{2}$ Furthermore, we considered birth cohort studies only to avoid possible bias deriving from the inclusion of prevalence studies. Thus our findings for AD are apparently different from those for asthma, which showed no clear association with pet exposure ${ }^{16}$ or, if any association were present, an increased risk for dog exposure. ${ }^{14}$

The different role played by pet exposure in patients with AD compared with those with asthma and hay fever could be due to the different effects of allergens in these diseases, at least in part. 
Furry pet allergens have an important and complex role in the onset of asthma and hay fever, whereas pet allergens are not mainly involved in AD occurrence.

A major issue to be clarified is why a favorable effect on AD emerged for dog and pet exposure but not for cat keeping. The gut microbial communities differ across various mammalian species. ${ }^{56}$ In particular, the fecal microbiota of dogs and cats is highly diverse, ${ }^{57}$ and it is likely that their skin and mucosal microbiomes differ as well. Thus, contact with dogs and cats can have a different effect on the risk of AD because of the diverse microbial exposures experienced by children living with these animal species. In fact, changes in the (intestinal) colonization pattern during infancy have been related to the increasing allergy prevalence in high-income countries ${ }^{58}$ through an effect of the microflora by driving the maturation of the immune system. ${ }^{59}$ Increasing evidence supports the latter hypothesis. ${ }^{60,61}$

The stronger inverse association observed in the United States than in European studies for both dog and pet exposure with AD and the lack of association reported in studies from Oceania and Japan are difficult to explain. The prevalence of pet owners, specifically cat owners, in a population might play a role in the variation of risks of allergic diseases (ie, through a community effect). ${ }^{16,62}$ However, we observed no clear relation between the prevalence of pet keeping and risk estimates of AD in the identified studies. Differences between populations in handling a dog/pet (eg, kept inside or outside the house and level of animal contact with infants/children) and a role of gene-environment interactions ${ }^{4,30,63,64}$ are other tentative explanations for the geographic variation in risks. In any case only a minority of studies were conducted outside Europe, thus limiting the scope for interpretation.

One of the major difficulties in the investigation of the relation between pet exposure and $\mathrm{AD}$ is the role of family history of allergic disease. In fact, the presence of allergy in the family, besides increasing the risk of allergic disease in the child, might lead to the avoidance or removal of pets, in particular cats, ${ }^{65}$ from the home and thus to reverse causation. We tried to overcome this problem by excluding cross-sectional studies, which are more prone to this problem, ${ }^{66}$ using, when available, estimates adjusted for family history of allergy and by means of subgroup analyses. Furthermore, summary estimates were not materially different among studies adjusting or not adjusting for family history of allergy, as well as among studies based on children with a family history of allergy or unselected with respect to the latter factor. However, only a small number of studies provided results among children with no family history of allergy. Another reassuring consideration against the role of reverse causation derives from the different results obtained for dog and cat exposure on $\mathrm{AD}$ risk because such bias would be expected to equally affect both relationships ${ }^{4}$ or, if any effect is present, to have a larger effect on the relation with cats.

In all 3 meta-analyses of dogs, cats, and pets and AD, results from different studies were moderately heterogeneous, with the $I^{2}$ value for inconsistency ranging between $45 \%$ and $55 \%$. This might be due to the fact that studies differed widely in their methods; that is, they were conducted among different populations using diverse diagnostic procedures and end points, assessed exposures at various ages, and were adjusted for different covariates. When we considered these aspects in subgroup analyses, however, we could not find any specific factor that adequately explained the inconsistency.

It was not possible to stratify studies directly by adjustment for pet avoidance behavior of parents. ${ }^{19}$ To obviate this problem, we used family history of allergy as a proxy variable of pet avoidance. This might be suitable for prospective studies, although some limits of this approach have been previously discussed. ${ }^{5,26}$ The number of studies was relatively small, and consequently, the statistical power of some subgroup analyses was limited. For example, our meta-analysis was not informative on the role of maternal pet exposure during pregnancy because only 2 studies had data on the issue. ${ }^{25,52} \mathrm{We}$ also considered the role of pet exposure on $\mathrm{IgE}$-associated $\mathrm{AD}$, as in our previous meta-analysis of probiotic use, ${ }^{67}$ but data were available from 1 cohort study only (reporting ORs of 0.56 [95\% CI, 0.28-1.14] at age 2 years and 1.05 [95\% CI $0.61-1.81]$ at age 5 years for exposure to dog or cat). ${ }^{7}$

The favorable effect of dog exposure on $\mathrm{AD}$ might be explained by the role of contact with microbial agents during early life, affecting the development of the immune system. Our findings thus provide support to the hygiene hypothesis.

We thank Dr Lorenzo Moja for advice on conducting the meta-analysis.

\section{Key messages}

- Exposure to dogs decreased the risk of AD in children by approximately $25 \%$, whereas no association emerged with cat exposure.

- The association might be explained by the role of contact with microbial agents during early life, affecting the development of the immune system.

\section{REFERENCES}

1. Bach JF. The effect of infections on susceptibility to autoimmune and allergic diseases. N Engl J Med 2002;347:911-20.

2. Strachan DP. Hay fever, hygiene, and household size. BMJ 1989;299:1259-60.

3. Eder W, von Mutius E. Hygiene hypothesis and endotoxin: what is the evidence? Curr Opin Allergy Clin Immunol 2004;4:113-7.

4. Gern JE, Reardon CL, Hoffjan S, Nicolae D, Li Z, Roberg KA, et al. Effects of dog ownership and genotype on immune development and atopy in infancy. J Allergy Clin Immunol 2004;113:307-14.

5. Lodge CJ, Lowe AJ, Gurrin LC, Matheson MC, Balloch A, Axelrad C, et al. Pets at birth do not increase allergic disease in at-risk children. Clin Exp Allergy 2012; 42:1377-85.

6. Nafstad P, Magnus P, Gaarder PI, Jaakkola JJ. Exposure to pets and atopy-related diseases in the first 4 years of life. Allergy 2001;56:307-12.

7. Sandini U, Kukkonen AK, Poussa T, Sandini L, Savilahti E, Kuitunen M. Protective and risk factors for allergic diseases in high-risk children at the ages of two and five years. Int Arch Allergy Immunol 2011;156:339-48.

8. Brunekreef B, Von Mutius E, Wong G, Odhiambo J, Garcia-Marcos L, Foliaki S Exposure to cats and dogs, and symptoms of asthma, rhinoconjunctivitis, and eczema. Epidemiology 2012;23:742-50.

9. Von Ehrenstein OS, Von Mutius E, Illi S, Baumann L, Bohm O, von Kries R. Reduced risk of hay fever and asthma among children of farmers. Clin Exp Allergy 2000;30:187-93.

10. Waser M, von Mutius E, Riedler J, Nowak D, Maisch S, Carr D, et al. Exposure to pets, and the association with hay fever, asthma, and atopic sensitization in rural children. Allergy 2005;60:177-84.

11. Oberle D, von Mutius E, von Kries R. Childhood asthma and continuous exposure to cats since the first year of life with cats allowed in the child's bedroom. Allergy 2003;58:1033-6.

12. von Mutius E, Braun-Fahrlander C, Schierl R, Riedler J, Ehlermann S, Maisch S, et al. Exposure to endotoxin or other bacterial components might protect against the development of atopy. Clin Exp Allergy 2000;30:1230-4.

13. Lau S, Illi S, Sommerfeld C, Niggemann B, Bergmann R, von Mutius E, et al. Early exposure to house-dust mite and cat allergens and development of childhood asthma: a cohort study. Multicentre Allergy Study Group. Lancet 2000; $356: 1392-7$

14. Takkouche B, Gonzalez-Barcala FJ, Etminan M, Fitzgerald M. Exposure to furry pets and the risk of asthma and allergic rhinitis: a meta-analysis. Allergy 2008;63:857-64. 
15. Chen CM, Heinrich J. Re: Exposure to furry pets and the risk of asthma and allergic rhinitis: a meta-analysis. Allergy 2009;64:494-5.

16. Chen CM, Tischer C, Schnappinger M, Heinrich J. The role of cats and dogs in asthma and allergy - a systematic review. Int J Hyg Environ Health 2010;213:1-31.

17. Lodrup Carlsen KC, Roll S, Carlsen KH, Mowinckel P, Wijga AH, Brunekreef B, et al. Does pet ownership in infancy lead to asthma or allergy at school age? Pooled analysis of individual participant data from 11 European birth cohorts. PLoS One 2012;7:e43214.

18. Flohr C, Yeo L. Atopic dermatitis and the hygiene hypothesis revisited. Curr Probl Dermatol 2011;41:1-34

19. Langan SM, Flohr C, Williams HC. The role of furry pets in eczema: a systematic review. Arch Dermatol 2007;143:1570-7.

20. Alm B, Aberg N, Erdes L, Mollborg P, Pettersson R, Norvenius SG, et al. Early introduction of fish decreases the risk of eczema in infants. Arch Dis Child 2009;94:11-5.

21. Almqvist C, Garden F, Kemp AS, Li Q, Crisafulli D, Tovey ER, et al. Effects of early cat or dog ownership on sensitisation and asthma in a high-risk cohort without disease-related modification of exposure. Paediatr Perinat Epidemiol 2010;24:171-8.

22. Biagini Myers JM, Wang N, LeMasters GK, Bernstein DI, Epstein TG, Lindsey MA, et al. Genetic and environmental risk factors for childhood eczema development and allergic sensitization in the CCAAPS cohort. J Invest Dermatol 2010; 130:430-7.

23. Bisgaard H, Halkjaer LB, Hinge R, Giwercman C, Palmer C, Silveira L, et al Risk analysis of early childhood eczema. J Allergy Clin Immunol 2009;123: 1355-60.e5.

24. Dom S, Droste JH, Sariachvili MA, Hagendorens MM, Oostveen E, Bridts CH, et al. Pre- and post-natal exposure to antibiotics and the development of eczema, recurrent wheezing and atopic sensitization in children up to the age of 4 years. Clin Exp Allergy 2010;40:1378-87

25. Roduit C, Wohlgensinger J, Frei R, Bitter S, Bieli C, Loeliger S, et al. Prenatal animal contact and gene expression of innate immunity receptors at birth are associated with atopic dermatitis. J Allergy Clin Immunol 2011;127:179-185.e1.

26. Almqvist C, Egmar AC, van Hage-Hamsten M, Berglind N, Pershagen G, Nordvall SL, et al. Heredity, pet ownership, and confounding control in a populationbased birth cohort. J Allergy Clin Immunol 2003;111:800-6.

27. Eller E, Roll S, Chen CM, Herbarth O, Wichmann HE, von Berg A, et al. Metaanalysis of determinants for pet ownership in 12 European birth cohorts on asthma and allergies: a GA2LEN initiative. Allergy 2008;63:1491-8.

28. Stroup DF, Berlin JA, Morton SC, Olkin I, Williamson GD, Rennie D, et al. Metaanalysis of observational studies in epidemiology: a proposal for reporting. Metaanalysis Of Observational Studies in Epidemiology (MOOSE) group. JAMA 2000;283:2008-12.

29. Pelucchi C. Pets exposure and risk of atopic dermatitis in the paediatric age. CRD Register 2012:CRD42012002908. Available at: www.crd.york.ac.uk/prospero/ display_record.asp?id=crd42012002908. Accessed April 30, 2013.

30. Bisgaard H, Simpson A, Palmer CNA, Bonnelykke K, McLean I, Mukhopadhyay S, et al. Gene-environment interaction in the onset of eczema in infancy: filaggrin lossof-function mutations enhanced by neonatal cat exposure. PLoS Med 2008;5:e131.

31. Zirngibl A, Franke K, Gehring U, von Berg A, Berdel D, Bauer CP, et al. Exposure to pets and atopic dermatitis during the first two years of life. A cohort study. Pediatr Allergy Immunol 2002;13:394-401.

32. Chen CM, Morgenstern V, Bischof W, Herbarth O, Borte M, Behrendt H, et al Dog ownership and contact during childhood and later allergy development. Eur Respir J 2008;31:963-73.

33. Purvis DJ, Thompson JM, Clark PM, Robinson E, Black PN, Wild CJ, et al. Risk factors for atopic dermatitis in New Zealand children at 3.5 years of age. $\mathrm{Br} \mathrm{J}$ Dermatol 2005; 152:742-9.

34. Linneberg A, Simonsen JB, Petersen J, Stensballe LG, Benn CS. Differential effects of risk factors on infant wheeze and atopic dermatitis emphasize a different etiology. J Allergy Clin Immunol 2006;117:184-9.

35. Sariachvili M, Droste J, Dom S, Wieringa M, Vellinga A, Hagendorens M, et al Is breast feeding a risk factor for eczema during the first year of life? Pediatr Allergy Immunol 2007;18:410-7.

36. Arshad SH. Pets and atopic disorders in infancy. Br J Clin Pract 1991;45:88-9.

37. DerSimonian R, Laird N. Meta-analysis in clinical trials. Control Clin Trials 1986; 7:177-88.

38. Greenland S. Quantitative methods in the review of epidemiologic literature. Epidemiol Rev 1987;9:1-30.

39. Bradburn MJ, Deeks JJ, Altman DG. sbe24: metan — an alternative meta-analysis command. Stata Tech Bull 1998;44:4-15.

40. Higgins JP, Thompson SG, Deeks JJ, Altman DG. Measuring inconsistency in meta-analyses. BMJ 2003;327:557-60.

41. Harris RJ, Bradburn MJ, Deeks JJ, Harbord RM, Altman DG, Sterne JAC. Metan: fixed- and random-effects meta-analysis. In: Sterne JAC, editor. Meta-analysis in
Stata: an updated collection from the Stata Journal. College Station (TX): Stata Press; 2009. p. 29-54.

42. Begg CB, Mazumdar M. Operating characteristics of a rank correlation test for publication bias. Biometrics 1994;50:1088-101.

43. Egger M, Davey Smith G, Schneider M, Minder C. Bias in meta-analysis detected by a simple, graphical test. BMJ 1997;315:629-34

44. Arshad SH, Hide DW. Effect of environmental factors on the development of allergic disorders in infancy. J Allergy Clin Immunol 1992;90:235-41.

45. Benn CS, Melbye M, Wohlfahrt J, Bjorksten B, Aaby P. Cohort study of sibling effect, infectious diseases, and risk of atopic dermatitis during first 18 months of life. BMJ 2004;328:1223

46. Hagendorens MM, Bridts CH, Lauwers K, van Nuijs S, Ebo DG, Vellinga A, et al. Perinatal risk factors for sensitization, atopic dermatitis and wheezing during the first year of life (PIPO study). Clin Exp Allergy 2005;35:733-40.

47. Bufford JD, Reardon CL, Li Z, Roberg KA, DaSilva D, Eggleston PA, et al. Effects of dog ownership in early childhood on immune development and atopic diseases. Clin Exp Allergy 2008;38:1635-43.

48. Dunlop AL, Reichrtova E, Palcovicova L, Ciznar P, Adamcakova-Dodd A, Smith SJ, et al. Environmental and dietary risk factors for infantile atopic eczema among a Slovak birth cohort. Pediatr Allergy Immunol 2006;17:103-11.

49. Epstein TG, Bernstein DI, Levin L, Khurana Hershey GK, Ryan PH, Reponen T, et al. Opposing effects of cat and dog ownership and allergic sensitization on eczema in an atopic birth cohort. J Pediatr 2011;158:265-71, e1-5.

50. Kerkhof M, Koopman LP, van Strien RT, Wijga A, Smit HA, Aalberse RC, et al. Risk factors for atopic dermatitis in infants at high risk of allergy: the PIAMA study. Clin Exp Allergy 2003;33:1336-41.

51. Ludvigsson JF, Mostrom M, Ludvigsson J, Duchen K. Exclusive breastfeeding and risk of atopic dermatitis in some 8300 infants. Pediatr Allergy Immunol 2005; $16: 201-8$

52. Miyake Y, Ohya Y, Tanaka K, Yokoyama T, Sasaki S, Fukushima W, et al. Home environment and suspected atopic eczema in Japanese infants: the Osaka Maternal and Child Health Study. Pediatr Allergy Immunol 2007;18:425-32.

53. Phipatanakul W, Celedon JC, Raby BA, Litonjua AA, Milton DK, Sredl D, et al. Endotoxin exposure and eczema in the first year of life. Pediatrics 2004;114:13-8

54. Tariq SM, Matthews SM, Hakim EA, Stevens M, Arshad SH, Hide DW. The prevalence of and risk factors for atopy in early childhood: a whole population birth cohort study. J Allergy Clin Immunol 1998;101:587-93.

55. Arshad SH, Stevens M, Hide DW. The effect of genetic and environmental factors on the prevalence of allergic disorders at the age of two years. Clin Exp Allergy 1993;23:504-11

56. Ley RE, Hamady M, Lozupone C, Turnbaugh PJ, Ramey RR, Bircher JS, et al. Evolution of mammals and their gut microbes. Science 2008;320:1647-51.

57. Handl S, Dowd SE, Garcia-Mazcorro JF, Steiner JM, Suchodolski JS. Massive parallel 16S rRNA gene pyrosequencing reveals highly diverse fecal bacterial and fungal communities in healthy dogs and cats. FEMS Microbiol Ecol 2011;76:301-10.

58. Wold AE. The hygiene hypothesis revised: is the rising frequency of allergy due to changes in the intestinal flora? Allergy 1998;53:20-5.

59. Bjorksten B, Sepp E, Julge K, Voor T, Mikelsaar M. Allergy development and the intestinal microflora during the first year of life. J Allergy Clin Immunol 2001;108:516-20.

60. Russell SL, Gold MJ, Hartmann M, Willing BP, Thorson L, Wlodarska M, et al Early life antibiotic-driven changes in microbiota enhance susceptibility to allergic asthma. EMBO Rep 2012;13:440-7.

61. Hill DA, Siracusa MC, Abt MC, Kim BS, Kobuley D, Kubo M, et al. Commensal bacteria-derived signals regulate basophil hematopoiesis and allergic inflammation. Nat Med 2012;18:538-46.

62. Svanes C, Heinrich J, Jarvis D, Chinn S, Omenaas E, Gulsvik A, et al. Pet-keeping in childhood and adult asthma and hay fever: European community respiratory health survey. J Allergy Clin Immunol 2003;112:289-300.

63. Simpson A, John SL, Jury F, Niven R, Woodcock A, Ollier WE, et al. Endotoxin exposure, CD14, and allergic disease: an interaction between genes and the environment. Am J Respir Crit Care Med 2006;174:386-92.

64. Irvine AD, McLean WH, Leung DY. Filaggrin mutations associated with skin and allergic diseases. N Engl J Med 2011;365:1315-27.

65. Gold DR, Burge HA, Carey V, Milton DK, Platts-Mills T, Weiss ST. Predictors of repeated wheeze in the first year of life: the relative roles of cockroach, birth weight, acute lower respiratory illness, and maternal smoking. Am J Respir Crit Care Med 1999;160:227-36.

66. Hennekens $\mathrm{CH}$, Buring JE. Epidemiology in medicine. Boston: Little, Brown \& Co; 1987.

67. Pelucchi C, Chatenoud L, Turati F, Galeone C, Moja L, Bach JF, et al. Probiotics supplementation during pregnancy or infancy for the prevention of atopic dermatitis: a meta-analysis. Epidemiology 2012;23:402-14. 

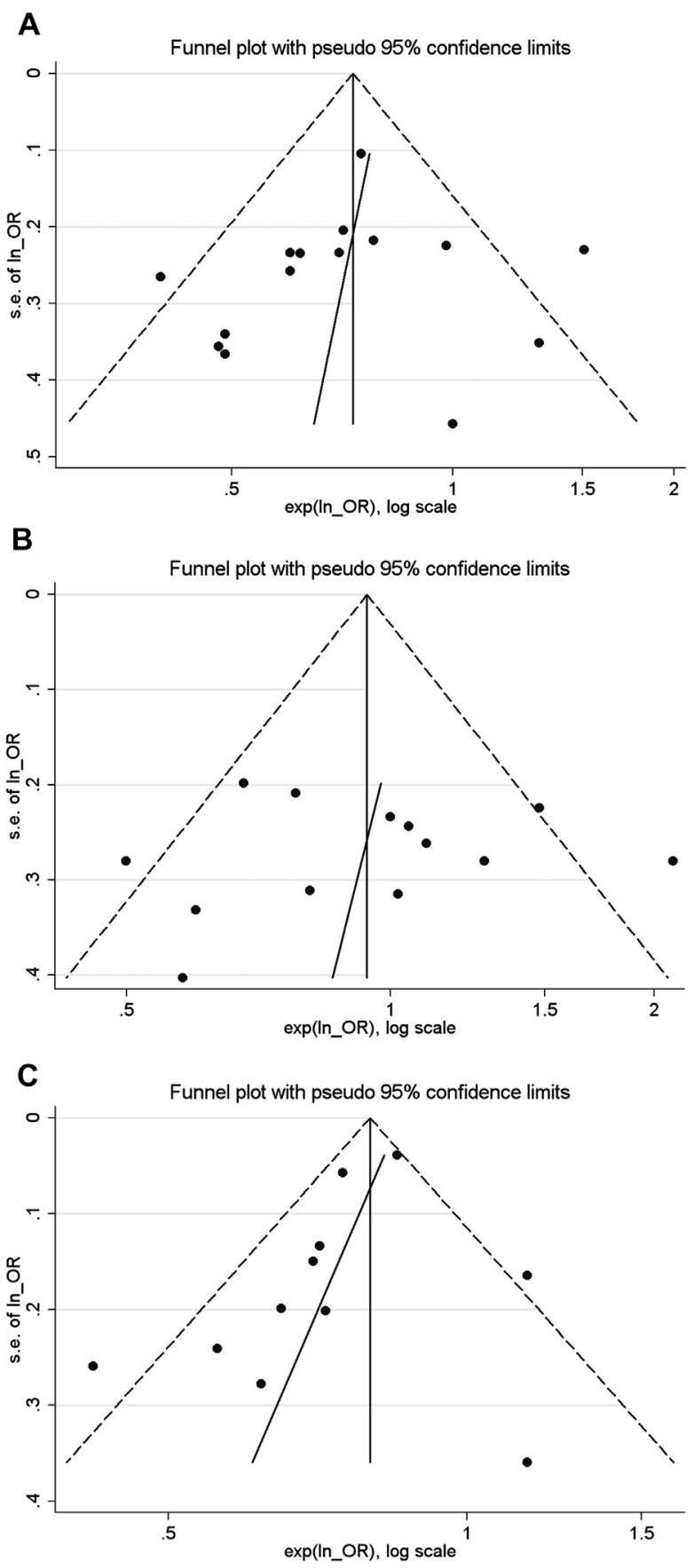

FIG E1. Funnel plots of studies on exposure to dogs (A), cats (B), and pets overall (C) and risk of $A D$. 


\begin{tabular}{|c|c|c|c|c|c|c|c|c|c|c|c|}
\hline Reference & Country & $\begin{array}{c}\text { Period of } \\
\text { enrollment }\end{array}$ & $\begin{array}{l}\text { Age at follow- } \\
\text { up's end }\end{array}$ & $\begin{array}{l}\text { Study design } \\
\text { (name) }\end{array}$ & $\begin{array}{c}\text { Pet } \\
\text { exposure }\end{array}$ & $\begin{array}{l}\text { Period of } \\
\text { exposure } \\
\text { assessment }\end{array}$ & $\begin{array}{l}\text { Outcome } \\
\text { assessment } \\
\text { for } A D\end{array}$ & $\begin{array}{c}\text { Type of } \\
\text { diagnosis }\end{array}$ & $\begin{array}{l}\text { No. of } \\
\text { subjects }\end{array}$ & $\begin{array}{l}\text { Adjustment } \\
\text { factors }\end{array}$ & $\begin{array}{l}\text { Data for } \\
\text { subgroups }\end{array}$ \\
\hline $\begin{array}{l}\text { Alm et al, } \\
2009^{20}\end{array}$ & Sweden & 2003 & $1 \mathrm{y}$ & $\begin{array}{l}\text { Birth cohort } \\
\text { (IWS) }\end{array}$ & $\begin{array}{l}\text { 1: Dog } \\
\text { 2: Cat (NS, NR) } \\
\text { 3: Bird } \\
\text { 4: Rodent }\end{array}$ & NR & Up to age $1 \mathrm{y}$ & Self-reported & 4,953 & $\begin{array}{l}\text { None: An } \\
\text { adjusted model } \\
\text { was used in } \\
\text { analysis on } \\
\text { dogs, but ORs } \\
\text { were not } \\
\text { reported. }\end{array}$ & None \\
\hline $\begin{array}{l}\text { Almqvist et al, } \\
2010^{21}\end{array}$ & Australia & 1997-1999 & $5 y$ & $\begin{array}{l}\text { Birth cohort } \\
\text { (CAPS) from } \\
\text { an RCT on } \\
\text { house dust } \\
\text { mite avoidance } \\
\text { and fatty acid } \\
\text { intake for the } \\
\text { prevention of } \\
\text { asthma and } \\
\text { allergic } \\
\text { diseases }\end{array}$ & $\begin{array}{l}\text { 1: Dog } \\
\text { 2: Cat }\end{array}$ & Up to age $5 \mathrm{y}$ & At age $5 \mathrm{y}$ & $\begin{array}{l}\text { Presence at } \\
\text { inspection or } \\
\text { parental report } \\
\text { of itchy rash } \\
\text { and use of } \\
\text { creams/seeking } \\
\text { medical care } \\
\text { referred to the } \\
\text { last } 12 \text { mo }\end{array}$ & $\begin{array}{l}516 \text { children } \\
\text { with family } \\
\text { history of } \\
\text { asthma or } \\
\text { wheeze and } \\
\text { without a } \\
\text { cat at } \\
\text { prenatal } \\
\text { enrollment }\end{array}$ & $\begin{array}{l}\text { 1: Sex, older } \\
\text { siblings, } \\
\text { family history } \\
\text { of asthma, } \\
\text { maternal } \\
\text { smoking } \\
\text { during } \\
\text { pregnancy, } \\
\text { breast-feeding, } \\
\text { intervention } \\
\text { group } \\
\text { 2: Same as 1, plus } \\
\text { environmental } \\
\text { tobacco smoke }\end{array}$ & None \\
\hline \multicolumn{12}{|c|}{ Isle of Wight cohort } \\
\hline $\begin{array}{l}\text { Arshad, } \\
1991^{36}\end{array}$ & $\begin{array}{l}\text { United } \\
\text { Kingdom }\end{array}$ & 1989-1990 & $1 \mathrm{y}$ & $\begin{array}{l}\text { Birth cohort } \\
\text { (Isle of } \\
\text { Wight) }\end{array}$ & Any pet & At age $1 \mathrm{y}$ & At age $1 \mathrm{y}$ & $\begin{array}{l}\text { Physical } \\
\text { examination }\end{array}$ & 1,111 & None & None \\
\hline $\begin{array}{l}\text { Arshad et al, } \\
1993^{55}\end{array}$ & $\begin{array}{l}\text { United } \\
\quad \text { Kingdom }\end{array}$ & 1989-1990 & $2 \mathrm{y}$ & $\begin{array}{l}\text { Birth cohort } \\
\text { (Isle of } \\
\text { Wight) }\end{array}$ & Dog or cat & At age $2 \mathrm{y}$ & At age $2 \mathrm{y}$ & $\begin{array}{l}\text { Physical } \\
\quad \text { examination }\end{array}$ & 1,174 & None & None \\
\hline $\begin{array}{c}\text { Tariq et al, } \\
1998^{54}\end{array}$ & $\begin{array}{l}\text { United } \\
\quad \text { Kingdom }\end{array}$ & 1989-1990 & $4 \mathrm{y}$ & $\begin{array}{l}\text { Birth cohort } \\
\text { (Isle of } \\
\text { Wight) }\end{array}$ & Any pet & At age $4 \mathrm{y}$ & At age $4 \mathrm{y}$ & $\begin{array}{l}\text { Physical } \\
\quad \text { examination }\end{array}$ & 1,218 & None & None \\
\hline \multicolumn{12}{|l|}{ CCAAPS cohort } \\
\hline $\begin{array}{l}\text { Biagini } \\
\text { Myers et } \\
\text { al, } 2010^{22}\end{array}$ & $\begin{array}{l}\text { United } \\
\text { States }\end{array}$ & 2001-2003 & $3 \mathrm{y}$ & $\begin{array}{l}\text { Birth cohort } \\
\text { (CCAAPS) }\end{array}$ & $\begin{array}{l}\text { 1: Dog } \\
\text { 2: Cat }\end{array}$ & At age 6-7 mo & $\begin{array}{l}\text { At age } 1 \mathrm{y} \text {; up to } \\
\text { age } 3 \mathrm{y} \text {; at both } \\
\text { ages } 2 \text { and } 3 \mathrm{y}\end{array}$ & $\begin{array}{l}\text { Parental report or } \\
\text { positive } \\
\text { physical } \\
\text { examination }\end{array}$ & $\begin{array}{l}762 \text { children } \\
\text { with } \geq 1 \\
\text { atopic } \\
\text { parent }\end{array}$ & None & None \\
\hline $\begin{array}{l}\text { Epstein et al, } \\
2011^{49}\end{array}$ & $\begin{array}{l}\text { United } \\
\text { States }\end{array}$ & 2001-2003 & $4 \mathrm{y}$ & $\begin{array}{l}\text { Birth cohort } \\
\text { (CCAAPS) }\end{array}$ & $\begin{array}{l}\text { 1: Dog } \\
\text { 2: Cat }\end{array}$ & $\begin{array}{l}\text { Up to age } 1 \text { y } \\
\text { (home visit) }\end{array}$ & At age $4 \mathrm{y}$ & Parental report & $\begin{array}{c}636 \text { children } \\
\text { with } \geq 1 \\
\text { atopic } \\
\text { parent }\end{array}$ & None & $\begin{array}{l}\text { African } \\
\text { Americans }\end{array}$ \\
\hline \multicolumn{12}{|l|}{ COPSAC cohort } \\
\hline $\begin{array}{l}\text { Bisgaard, } \\
2008^{30}\end{array}$ & $\begin{array}{l}\text { Denmark } \\
\text { and United } \\
\text { Kingdom }\end{array}$ & $\begin{array}{c}\text { 1998-2001 } \\
\text { (COPSAC) } \\
1995-1997 \\
\text { (MAAS) }\end{array}$ & $1 \mathrm{y}$ & $\begin{array}{l}\text { Two birth } \\
\text { cohorts } \\
\text { (COPSAC } \\
\text { and MAAS) }\end{array}$ & $\begin{array}{l}\text { 1: Dog } \\
\text { 2: Both dog and } \\
\text { cat (not } \\
\text { allowing to } \\
\text { compute ORs } \\
\text { for "dog or } \\
\text { cat") }\end{array}$ & At birth & $\begin{array}{l}\text { Up to age } 1 \mathrm{y} \\
\text { (hazard ratio) }\end{array}$ & $\begin{array}{l}\text { Clinical } \\
\text { examination } \\
\text { (COPSAC) or } \\
\text { parental report } \\
\text { (MAAS) }\end{array}$ & $\begin{array}{l}379 \text { children } \\
\text { of mothers } \\
\text { with asthma } \\
\text { (COPSAC) } \\
\text { and } 503 \\
\text { unselected } \\
\text { children } \\
\text { (MAAS) }\end{array}$ & None & $\begin{array}{l}\text { COPSAC and } \\
\text { MAAS } \\
\text { separately: cat } \\
\text { exposure, } \\
\text { according to } \\
\text { filaggrin } \\
\text { mutations }\end{array}$ \\
\hline
\end{tabular}




\begin{tabular}{|c|c|c|c|c|c|c|c|c|c|c|c|}
\hline $\begin{array}{l}\text { Bisgaard et } \\
\text { al, } 2009^{23}\end{array}$ & Denmark & 1998-2001 & $3 y$ & $\begin{array}{l}\text { Birth cohort } \\
\text { (COPSAC) }\end{array}$ & $\begin{array}{l}\text { 1: Dog } \\
\text { 2: Cat }\end{array}$ & At birth & Up to age $3 y$ & $\begin{array}{l}\text { Physical } \\
\text { examination or } \\
\text { history of AD } \\
\text { collected by } \\
\text { the doctor. } \\
\text { Hanifin and } \\
\text { Rajka criteria }\end{array}$ & $\begin{array}{l}356 \text { children } \\
\text { of mothers } \\
\text { with asthma }\end{array}$ & $\begin{array}{l}\text { 1: NR, based on } \\
\text { stepwise } \\
\text { selection } \\
\text { 2: None }\end{array}$ & $\begin{array}{l}\text { Parental } \\
\text { sensitization } \\
\text { to dogs }\end{array}$ \\
\hline \multicolumn{12}{|l|}{ COAST cohort } \\
\hline $\begin{array}{l}\text { Bufford et al, } \\
2008^{47}\end{array}$ & $\begin{array}{l}\text { United } \\
\text { States }\end{array}$ & 1998-2000 & $3 y$ & $\begin{array}{r}\text { Birth cohort } \\
(\text { COAST })\end{array}$ & $\begin{array}{l}\text { 1: Dog } \\
\text { 2: Cat (NS, NR) }\end{array}$ & $\begin{array}{l}\text { At birth; at age } 3 \\
y\end{array}$ & $\begin{array}{l}\text { Up to age } 3 \mathrm{y} \text {; at } \\
\text { age } 3 \mathrm{y}\end{array}$ & $\begin{array}{l}\text { Diagnosed by a } \\
\text { physician (by } \\
\text { documents or } \\
\text { reported by a } \\
\text { parent) }\end{array}$ & $\begin{array}{l}275 \text { children } \\
\text { with } \geq 1 \\
\text { parent with } \\
\text { respiratory } \\
\text { allergy } \\
\text { and/or } \\
\text { asthma }\end{array}$ & $\begin{array}{l}\text { Ethnicity, older } \\
\text { siblings, day } \\
\text { care } \\
\text { attendance, } \\
\text { RSV infection } \\
\text { in infancy, } \\
\text { smoke } \\
\text { exposure in } \\
\text { infancy, } \\
\text { maternal and } \\
\text { paternal } \\
\text { history of } \\
\text { asthma and } \\
\text { allergy, family } \\
\text { income, } \\
\text { maternal and } \\
\text { paternal } \\
\text { education }\end{array}$ & None \\
\hline $\begin{array}{l}\text { Gern et al, } \\
2004^{4}\end{array}$ & $\begin{array}{l}\text { United } \\
\text { States }\end{array}$ & $1998-2001$ & $1 \mathrm{y}$ & $\begin{array}{r}\text { Birth cohort } \\
(\text { COAST })\end{array}$ & $\begin{array}{l}\text { 1: Dog } \\
\text { 2: Cat } \\
\text { 3: Both dog and } \\
\text { cat (allowing } \\
\text { to compute } \\
\text { ORs for "dog } \\
\text { or cat" as well) }\end{array}$ & At birth & $\begin{array}{l}\text { Up to age } 1 \mathrm{y} \text {; } \\
\text { at age } 1 \mathrm{y}\end{array}$ & $\begin{array}{l}\text { Diagnosed by a } \\
\text { physician (by } \\
\text { documents or } \\
\text { reported by a } \\
\text { parent) }\end{array}$ & $\begin{array}{l}285 \text { children } \\
\text { with } \geq 1 \text { parent } \\
\text { with } \\
\text { respiratory } \\
\text { allergy or } \\
\text { asthma }\end{array}$ & None & $\begin{array}{l}\text { Dog exposure } \\
\text { by CD14 } \\
\text { genotype }\end{array}$ \\
\hline \multicolumn{12}{|l|}{ GINI cohort } \\
\hline $\begin{array}{l}\text { Chen et al, } \\
2008^{32}\end{array}$ & Germany & $\begin{array}{l}1995-1998 \\
(\mathrm{GINI}) \\
1997-1999 \\
\text { (LISA) }\end{array}$ & $6 y$ & $\begin{array}{l}\text { Birth cohorts } \\
\text { (LISA and } \\
\text { GINI: the } \\
\text { latter } \\
\text { is a } 2 \text {-arm } \\
\text { study: } 1 \\
\text { interventional } \\
\text { and } 1 \text { non- } \\
\text { interventional) }\end{array}$ & Dog & $\begin{array}{l}\text { Up to age } 1 \mathrm{y} \text {; up } \\
\text { to age } 4 \mathrm{y}\end{array}$ & $\begin{array}{c}\text { Between ages } 4 \\
\text { and } 6 \mathrm{y}\end{array}$ & $\begin{array}{l}\text { Self-report of } \\
\text { doctor- } \\
\text { diagnosed AD } \\
\text { (data on } \\
\text { presence of } \\
\text { symptoms of } \\
\text { AD were also } \\
\text { given) }\end{array}$ & $\begin{array}{l}\text { 2,083 (GINI1, non- } \\
\text { intervention) } \\
\text { and } 1,632 \\
\text { (GINI2, } \\
\text { intervention) } \\
\text { children with } \\
\text { family history } \\
\text { of allergic } \\
\text { disease and } \\
2,171 \\
\text { unselected } \\
\text { children } \\
\text { (LISA) }\end{array}$ & $\begin{array}{l}\text { Sex, parental } \\
\text { history of } \\
\text { allergy, } \\
\text { parental } \\
\text { education and } \\
\text { study center: } \\
\text { Further ORs } \\
\text { adjusted for cat } \\
\text { ownership and } \\
\text { frequent } \\
\text { contact with } \\
\text { cats were } \\
\text { given. Results } \\
\text { were } \\
\text { unaffected. }\end{array}$ & None \\
\hline
\end{tabular}




\begin{tabular}{|c|c|c|c|c|c|c|c|c|c|c|c|}
\hline Reference & Country & $\begin{array}{c}\text { Period of } \\
\text { enrollment }\end{array}$ & $\begin{array}{l}\text { Age at follow- } \\
\text { up's end }\end{array}$ & $\begin{array}{l}\text { Study design } \\
\text { (name) }\end{array}$ & $\begin{array}{c}\text { Pet } \\
\text { exposure }\end{array}$ & $\begin{array}{c}\text { Period of } \\
\text { exposure } \\
\text { assessment }\end{array}$ & $\begin{array}{l}\text { Outcome } \\
\text { assessment } \\
\text { for } A D\end{array}$ & $\begin{array}{c}\text { Type of } \\
\text { diagnosis }\end{array}$ & $\begin{array}{c}\text { No. of } \\
\text { subjects }\end{array}$ & $\begin{array}{c}\text { Adjustment } \\
\text { factors }\end{array}$ & $\begin{array}{c}\text { Data for } \\
\text { subgroups }\end{array}$ \\
\hline $\begin{array}{l}\text { Zirngibl et al, } \\
2002^{31}\end{array}$ & Germany & 1996-1998 & $2 \mathrm{y}$ & $\begin{array}{l}\text { Birth cohort } \\
\text { (GINI, a 2-arm } \\
\text { study, 1 } \\
\text { interventional } \\
\text { and 1 non- } \\
\text { interventional) }\end{array}$ & $\begin{array}{l}\text { 1: Dog } \\
\text { 2: Cat } \\
\text { 3: Hamster, } \\
\quad \text { rabbit, or } \\
\text { guinea pig } \\
\text { 4: Other } \\
\text { 5: Any pet }\end{array}$ & Up to age $1 \mathrm{y}$ & $\begin{array}{l}\text { Up to age } 1 \mathrm{y} ; \\
\text { between ages } \\
1 \text { and } 2 \mathrm{y}\end{array}$ & $\begin{array}{l}\text { Parental report of } \\
\text { a physician's } \\
\text { diagnosis of } \\
\text { AD }\end{array}$ & 4,578 & $\begin{array}{l}\text { Sex, siblings, } \\
\text { family history } \\
\text { of atopic } \\
\text { diseases, } \\
\text { parental } \\
\text { education and } \\
\text { nationality, } \\
\text { living } \\
\text { surroundings, } \\
\text { environmental } \\
\text { tobacco } \\
\text { smoke, } \\
\text { gestational } \\
\text { age, breast- } \\
\text { feeding, study } \\
\text { area, and study } \\
\text { group }\end{array}$ & None \\
\hline $\begin{array}{l}\text { Dunlop et al, } \\
2006^{48}\end{array}$ & $\begin{array}{l}\text { Slovak } \\
\text { Republic }\end{array}$ & 1997-1999 & $1 \mathrm{y}$ & Birth cohort & $\begin{array}{l}\text { 1: Cat } \\
\text { 2: Bird } \\
\text { 3: Other furred } \\
\text { pet (ie, dog, } \\
\text { hamster, } \\
\text { guinea pig, } \\
\text { rabbit) }\end{array}$ & NR & Up to age $1 \mathrm{y}$ & $\begin{array}{l}\text { Physical } \\
\text { examination } \\
\text { yielding a } \\
\text { SCORAD } \\
\text { score }>2 \text { or } \\
\text { physician's } \\
\text { diagnosis } \\
\text { reported by } \\
\text { parents }\end{array}$ & 1,326 & $\begin{array}{l}\text { Family history of } \\
\text { atopy, parental } \\
\text { education, } \\
\text { region, } \\
\text { residential } \\
\text { factors, fuel } \\
\text { used for } \\
\text { heating and } \\
\text { cooking, } \\
\text { parental } \\
\text { smoking, } \\
\text { household } \\
\text { exposures, } \\
\text { pregnancy } \\
\text { factors and } \\
\text { infant feeding }\end{array}$ & None \\
\hline $\begin{array}{l}\text { Kerkhof et al, } \\
2003^{50}\end{array}$ & $\begin{array}{l}\text { The } \\
\text { Netherlands }\end{array}$ & 1996-1997 & $1 \mathrm{y}$ & $\begin{array}{l}\text { Birth cohort } \\
\text { (PIAMA, } \\
\text { intervention } \\
\text { arm from a } \\
\text { double-blind } \\
\text { placebo- } \\
\text { controlled trial } \\
\text { on preventive } \\
\text { effect of } \\
\text { mattress } \\
\text { covers) }\end{array}$ & $\begin{array}{l}\text { 1: Dog } \\
\text { 2: Cat }\end{array}$ & NR & $\begin{array}{l}\text { At } 1 \mathrm{y} \text { (vs never } \\
\text { AD) }\end{array}$ & $\begin{array}{l}\text { Physical } \\
\text { examination, } \\
\text { according to } \\
\text { the modified } \\
\text { UK Working } \\
\text { Party criteria }\end{array}$ & $\begin{array}{l}304 \text { children } \\
\text { of mothers } \\
\text { with } \\
\text { respiratory } \\
\text { allergy or } \\
\text { asthma }\end{array}$ & $\begin{array}{l}\text { Sex, siblings, day } \\
\text { care } \\
\text { attendance, } \\
\text { birth weight, } \\
\text { gestational } \\
\text { age, age of } \\
\text { mother, region, } \\
\text { parental } \\
\text { education, } \\
\text { parental } \\
\text { smoking, and } \\
\text { breast-feeding }\end{array}$ & $\begin{array}{l}\text { Cat and dog } \\
\text { exposure } \\
\text { according to } \\
\text { presence or } \\
\text { absence of } \\
\text { symptoms of } \\
\text { AD at } 3 \text { mo }\end{array}$ \\
\hline
\end{tabular}




\begin{tabular}{|c|c|c|c|c|c|c|c|c|c|c|c|}
\hline $\begin{array}{l}\text { Linneberg et } \\
\text { al, } 2006^{34}\end{array}$ & Denmark & 1997-2002 & $1.5 \mathrm{y}$ & $\begin{array}{l}\text { Birth cohort } \\
\text { (DNBC) }\end{array}$ & Any pet & Up to age $1.5 \mathrm{y}$ & Up to age $1.5 \mathrm{y}$ & $\begin{array}{l}\text { Maternal report } \\
\text { of a physician's } \\
\text { diagnosis of } \\
\text { AD and } \\
\text { recurrent rash } \\
\text { with relevant } \\
\text { localization }\end{array}$ & 34,793 & $\begin{array}{l}\text { Sex older } \\
\text { siblings, } \\
\text { season of } \\
\text { birth, head } \\
\text { circumference, } \\
\text { birth weight, } \\
\text { day care before } \\
6 \text { mo, parental } \\
\text { history of } \\
\text { allergy, } \\
\text { maternal age } \\
\text { and } \\
\text { occupation, } \\
\text { farm } \\
\text { residence, } \\
\text { family income, } \\
\text { gestational } \\
\text { age, smoking } \\
\text { during } \\
\text { pregnancy, } \\
\text { and breast- } \\
\text { feeding }\end{array}$ & None \\
\hline $\begin{array}{l}\text { Lodge et al, } \\
2012^{5}\end{array}$ & Australia & 1990-1994 & $12 \mathrm{y}$ & $\begin{array}{l}\text { Birth cohort } \\
\text { (MACS) of } \\
\text { an RCT on } \\
\text { infant } \\
\text { formulas }\end{array}$ & $\begin{array}{l}\text { 1: Cat } \\
\text { 2: Dog } \\
\text { 3: Dog or cat }\end{array}$ & At birth & $\begin{array}{r}\text { At age } 2 \mathrm{y} ; \text { at age } \\
7 \mathrm{y} ; \text { at age } 12 \mathrm{y}\end{array}$ & $\begin{array}{l}\text { Doctor } \\
\text { consultation } \\
\text { for } \mathrm{AD} \text { or } \\
\text { treatment }\end{array}$ & $\begin{array}{l}620 \text { children } \\
\text { with } \geq 1 \\
\text { parent or } \\
\text { sibling with } \\
\text { history of } \\
\text { allergic } \\
\text { diseases ( } 359 \\
\text { followed until } \\
12 \text { y of age) }\end{array}$ & $\begin{array}{l}\text { Sex, parental } \\
\text { history of } \\
\text { asthma, } \mathrm{AD}, \\
\text { hay fever and } \\
\text { atopy, parental } \\
\text { smoking status, } \\
\text { household } \\
\text { carpets, and } \\
\text { government } \\
\text { assistance }\end{array}$ & None \\
\hline $\begin{array}{l}\text { Ludvigsson } \\
\text { et al, } \\
2005^{51}\end{array}$ & Sweden & 1997-1999 & $1 \mathrm{y}$ & $\begin{array}{l}\text { Birth cohort } \\
\text { (ABIS) }\end{array}$ & $\begin{array}{l}\text { Furred pets (ie, } \\
\text { dog, cat, or } \\
\text { guinea pig) }\end{array}$ & NR & $\begin{array}{l}\text { Up to age } 1 \mathrm{y} \\
\text { severe } \mathrm{AD} \text { (ie, } \\
\geq 3 \mathrm{AD} \\
\text { episodes) }\end{array}$ & Maternal report & 8,346 & $\begin{array}{l}\text { Siblings, preterm } \\
\text { birth, family } \\
\text { history of } \\
\text { atopy, parental } \\
\text { smoking status, } \\
\text { maternal } \\
\text { education, and } \\
\text { breast-feeding }\end{array}$ & $\begin{array}{l}\text { Family history of } \\
\text { atopy }\end{array}$ \\
\hline $\begin{array}{l}\text { Miyake et al, } \\
2007^{52}\end{array}$ & Japan & 2001-1003 & $2-9 \mathrm{mo}$ & $\begin{array}{l}\text { Birth cohort } \\
\text { (OMCHS) }\end{array}$ & $\begin{array}{l}\text { Indoor domestic } \\
\text { pets (ie, dog, } \\
\text { cat, bird, or } \\
\text { hamster) }\end{array}$ & During pregnancy & Up to age $2-9 \mathrm{mo}$ & $\begin{array}{l}\text { Maternal report of } \\
\text { diagnosis or } \\
\text { treatment for } \\
\mathrm{AD}\end{array}$ & 865 & $\begin{array}{l}\text { Sex, older } \\
\text { siblings, birth } \\
\text { weight, } \\
\text { parental } \\
\text { history of } \\
\text { atopic } \\
\text { diseases, } \\
\text { maternal age, } \\
\text { gestational } \\
\text { age, family } \\
\text { income, } \\
\text { parental } \\
\text { education, and } \\
\text { time of } \\
\text { delivery before } \\
\text { second survey }\end{array}$ & None \\
\hline
\end{tabular}




\begin{tabular}{|c|c|c|c|c|c|c|c|c|c|c|c|}
\hline Reference & Country & $\begin{array}{c}\text { Period of } \\
\text { enrollment }\end{array}$ & $\begin{array}{l}\text { Age at follow- } \\
\text { up's end }\end{array}$ & $\begin{array}{l}\text { Study design } \\
\text { (name) }\end{array}$ & $\begin{array}{c}\text { Pet } \\
\text { exposure }\end{array}$ & $\begin{array}{c}\text { Period of } \\
\text { exposure } \\
\text { assessment }\end{array}$ & $\begin{array}{l}\text { Outcome } \\
\text { assessment } \\
\text { for } A D\end{array}$ & $\begin{array}{c}\text { Type of } \\
\text { diagnosis }\end{array}$ & $\begin{array}{c}\begin{array}{c}\text { No. of } \\
\text { subjects }\end{array}\end{array}$ & $\begin{array}{l}\text { Adjustment } \\
\text { factors }\end{array}$ & $\begin{array}{c}\text { Data for } \\
\text { subgroups }\end{array}$ \\
\hline $\begin{array}{l}\text { Nafstad et al, } \\
2001^{6}\end{array}$ & Norway & 1992-1993 & $4 \mathrm{y}$ & $\begin{array}{l}\text { Birth cohort } \\
\text { (OBCS) }\end{array}$ & $\begin{array}{l}\text { 1: Dog } \\
\text { 2: Cat } \\
\text { 3: Any pet }\end{array}$ & At birth & Up to age $6 \mathrm{mo}$ & Parental report & 2,347 & $\begin{array}{l}\text { Sex, older } \\
\text { siblings, birth } \\
\text { weight, } \\
\text { parental } \\
\text { history of } \\
\text { atopy, } \\
\text { gestational } \\
\text { age, maternal } \\
\text { education, } \\
\text { family income, } \\
\text { and } \\
\text { environmental } \\
\text { tobacco smoke }\end{array}$ & $\begin{array}{l}\text { History of atopy } \\
\text { in parents }\end{array}$ \\
\hline $\begin{array}{l}\text { Phipatanakul } \\
\text { et al, } \\
2004^{53}\end{array}$ & $\begin{array}{l}\text { United } \\
\text { States }\end{array}$ & 1994-1996 & $1 \mathrm{y}$ & $\begin{array}{l}\text { Birth cohort } \\
\text { (HAAS) }\end{array}$ & $\begin{array}{l}\text { 1: Dog } \\
\text { 2: Cat }\end{array}$ & At age $2-3 \mathrm{mo}$ & Up to age $1 \mathrm{y}$ & $\begin{array}{l}\text { Parental report of } \\
\text { a diagnosis of } \\
\mathrm{AD}\end{array}$ & $\begin{array}{l}498 \text { children } \\
\text { with parental } \\
\text { history of } \\
\text { asthma or } \\
\text { allergy }\end{array}$ & $\begin{array}{l}\text { 1: Sex, season of } \\
\text { birth, paternal } \\
\text { history of AD, } \\
\text { family income, } \\
\text { maternal IgE } \\
\text { positivity } \\
\text { 2: None }\end{array}$ & None \\
\hline $\begin{array}{l}\text { Purvis et al, } \\
2005^{33}\end{array}$ & $\begin{array}{l}\text { New } \\
\text { Zealand }\end{array}$ & 1995-1997 & $3.5 \mathrm{y}$ & $\begin{array}{l}\text { Birth cohort } \\
\text { (ABC, } \\
\text { designed as } \\
\text { a case-control } \\
\text { study of SGA } \\
\text { infants, with } \\
\text { SGA and AGA } \\
\text { infants being } \\
\text { sampled with } \\
\text { different } \\
\text { probabilities } \\
\text { of selection) }\end{array}$ & $\begin{array}{l}\text { 1: Dog } \\
\text { 2: Cat }\end{array}$ & $\begin{array}{l}\text { Up to age } 1 \mathrm{y} ; \text { at } \\
\text { age } 3.5 \mathrm{y}\end{array}$ & At age $3.5 \mathrm{y}$ & $\begin{array}{l}\text { Physical } \\
\text { examination, } \\
\text { according to } \\
\text { the modified } \\
\text { UK Working } \\
\text { Party criteria }\end{array}$ & 550 & None & None \\
\hline $\begin{array}{l}\text { Roduit et al, } \\
2011^{25}\end{array}$ & $\begin{array}{l}\text { Europe }(5 \\
\quad \text { countries) }\end{array}$ & 2002-2005 & $2 \mathrm{y}$ & $\begin{array}{l}\text { Birth cohort } \\
\text { (PASTURE- } \\
\text { EFRAIM) }\end{array}$ & $\begin{array}{l}\text { 1: Dog } \\
\text { 2: Cat } \\
\text { 3: Any pet }\end{array}$ & $\begin{array}{l}\text { During pregnancy } \\
\quad \text { (third } \\
\text { trimester) }\end{array}$ & Up to age $2 \mathrm{y}$ & $\begin{array}{l}\text { Parental report of } \\
\text { a physician's } \\
\text { diagnosis of } \\
\text { AD }\end{array}$ & 1,063 & $\begin{array}{l}\text { Sex, maternal } \\
\text { history of } \\
\text { atopic } \\
\text { diseases, } \\
\text { maternal } \\
\text { smoking } \\
\text { during } \\
\text { pregnancy, } \\
\text { farming status, } \\
\text { and center }\end{array}$ & $\begin{array}{l}\text { Exposure to cats } \\
\text { by various } \\
\text { subgroups of } \\
\text { Toll-like } \\
\text { receptor } \\
\text { genotypes }\end{array}$ \\
\hline $\begin{array}{l}\text { Sandini et al, } \\
2011^{7}\end{array}$ & Finland & $2000-2003$ & $5 \mathrm{y}$ & $\begin{array}{l}\text { Birth cohort } \\
\text { of an RCT } \\
\text { of probiotic } \\
\text { use }\end{array}$ & Dog or cat & $\begin{array}{l}\text { Up to age } 2 \text { y; up } \\
\text { to age } 5 \mathrm{y}\end{array}$ & $\begin{array}{l}\text { Up to age } 2 \text { y; up } \\
\text { to age } 5 \text { y: } \\
\text { Results for } \\
\text { IgE-associated } \\
\text { AD were also } \\
\text { given. }\end{array}$ & $\begin{array}{l}\text { Physical } \\
\quad \text { examination }\end{array}$ & $\begin{array}{l}934 \text { children } \\
\text { with } \geq 1 \\
\text { parent with } \\
\text { allergic disease }\end{array}$ & $\begin{array}{l}\text { Allocation group } \\
\text { (probiotics or } \\
\text { placebo) and } \\
\text { interaction } \\
\text { term (treatment } \\
\text { group*presence } \\
\text { of dog/cat) }\end{array}$ & None \\
\hline
\end{tabular}




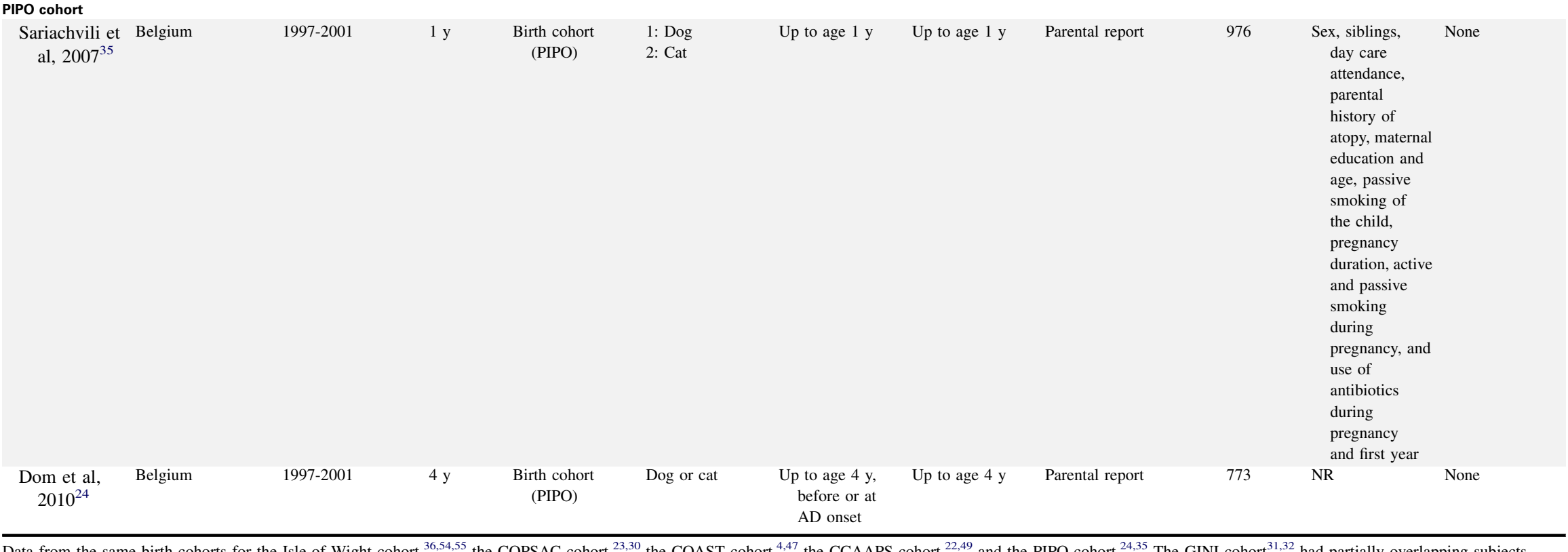

$A D$, Atopic dermatitis; $A G A$, appropriate for gestational age; $N R$, not reported; $N S$, not significant; $R C T$, randomized clinical trial; $R S V$, respiratory syncytial virus; $S G A$, small for gestational age. 